\title{
COMPARATIVE STUDY OF METFORMIN AND CAPTOPRIL ON INSULIN SENSITIVITY IN HIGH-FRUCTOSE FED RATS
}

\author{
By \\ Somaia A. w.ukbel \& Karawan M. Abdel Rahman
}

\author{
From \\ Department of Clinical Pharmacology \\ Faculty of Medicine, Mansoura University, Egypt
}

Received for Publication 15 April 2001

\begin{abstract}
Insulin resistance or compensatory hyperinsulinemia has been associated with dyslipidemia. Tumour necrosis factor-( (TNF- $\alpha$ ) may be an important circulating cytokine which may provide a potentially reversible mechanism for mediating insulin resistance.

The present study was carried out to compare the Le: sicicial effect of either the oral antidiabetic (metformin) or the angiotensin converting enzyme inhibitor (captopril) on insulin sensitivity in rats fed highfructose diet for 9 weeks. Other contribution of this work is to find if the improving effect of metformin or captopril on insulin resistance occurs through modulation of TNF- $\alpha$ or not.
\end{abstract}

108 male albino rats were used throughout this study. The animals were divided into 6 equal groups $(n=18)$. Group (1) served as a control received standard diet for 9 weeks. Group (2) received high fructose diet for 9 weeks. Group (3) received standard diet for 9 weeks and metformin treatment in a dose of $200 \mathrm{mg} / \mathrm{kg} /$ day in the last 3 weeks. Group (4) received high fructose diet for 9 weeks and metformin treatment in the last 3 weeks. Group (5) received standard diet for 9 weeks and captopril treatment in a dose of $2 \mathrm{mg} / \mathrm{kg} /$ day in the last 3 weeks. Group (6) received high fructose diet for 9 weeks and captopril treatment in the last 3 weeks. Insulin sensitivity test, intravenous glucose tolerance test (IVGTT), fasting serum insulin were all used to determine insulin sensitivity. In addition lipogram MANSOURA MEDICAL JOURNAL 
and serum TNF- $\alpha$ were measured. Rats fed high fructose diet develuped a significant insulin resistance as evidenced by impaired response to IP injection of insulin in a dose of $1 \mathrm{u} / \mathrm{kg}$ body weight. Also these rats showed impaired response to IVGTT. Furthermore these rats showed a significant increase in fasting serum insulin, TNF- $\alpha$, triglycerides (TG), low density lipoproteins (LDL) with a significant decrease in high density lipoprotein (HDL) and no change in serum glucose and cholesterol levels. Administration of metformin or captopril to rats fed high fructose diet produced a beneficial comparable effect on insulin resistance, dyslipidemia \& restored fasting serum insulin \& TNF- $\alpha$ to control levels. A fall in TNF- $\alpha$ concentration may contribute to the restoration of insulin sensitivity. Furthermore these results suggest that metfo:min or captopril treatrnent could improve insulin resistance \& dyslipidemia induced by a diet high in fructose \& that these drugs might prove useful in the treatment of nonhyperglycaemic insulin resistant states.

\section{INTRODUCTION}

Insulin resistance is a systemic phenomenon associated with several Vol. 32, No. 1 \& 2 Jan. \& April, 2001 diseases including chronic infection (1), cancer (2), obesity and especially non-insulin dependent diabetes mellitus (NIDDM) (3). Insulin resistance or hyperinsulinemia has been consistntly associated with dyslipidemia in the form of hypertriglyceridemia and a decreased serum HDL and increased cholesterol level in cross sectional studies $(4,5)$.

Tumour necrosis factor ( (TNF- $\alpha$ ) is a peptide constitutively expressed and secreted by adipose tissue (6). It has been demonstrated that TNF- $\alpha$ may be a mediator of insulin resistance that is known to occur in obese mice ( 7$)$. TNF- $\alpha$ interferes with insulin action, probably by inhibiting tyrosine kinase activity of insulin receptors (8). Phosphorylation of the insulin receptor by this tyrosine kinase is known to be a cardinal step in the post receptor events that follow the binding of insulin to its receptor (9). Furthermore, it has been shown that, in adipocytes from obese subjects, the expression of TNF- $\alpha$ message and protein falls markedly after weight loss (10).

Metformin is a biguanide used extensively in type 2 diabetes. It inhibits hepatic glucose production \& increases peripheral insulin sensitivity, but 
doesn't cause hypoglycaemia (11). The mode of action of metformin is still incompletely understood; however, it appears that its major effects involvo decreasing hepatic glucose cutritut and thus lowering the insulin requirement (11). Metformin also may improve insulin sensitivity and decrease insulin levels by decreasing gut absorption of glucose, improving glucose uptake by tissues \& increasing the number of insulin receptors (12\& 13).

Angiotensin converting enzyme inhibitors (ACEIs) have well documented effects in reducing blood pressure and improving other cardiovascular parameters in hypertensive individuals. The influence of ACE inhibitors, such as captopril, on glucose metabolism has also been studied, several clinical studies have shown that short and long term administration of captopril results in an increased insulin stimulated glucose disposal in diabetic or hypertensive individuals $(14,15,16)$. The short term oral administration of captopril at dosages that have no effect on blood pressure has been reported to improve peripheral glucose utilization (17). However, it is currently unclear whether this captopril induced im- provement in whole body disposal results from an alteration in skeletal muscle insulin signaling pathways, from improved muscle blood flow, or even from the combination of both (18). It has been suggested that ACE inhibitors may exert their effect on insulin sensitivity not only by blocking the renin angiotensin and kinin system but also by inhibiting production and/or release of endothelin (19). Rats fed with high dosages of fructose developed insulin resistance therefore, this study was undertaken to determine whether metformin or captopril could improve insulin resistance and the related abnormalities induced by high fructose diet feeding in normal rats.

\section{MATERIALS \& METHODS}

\section{Drugs used:}

Metformin: Glucophage tablets, $500 \mathrm{mg}$ supplied by Cid Co.

Captopril: Capoten tablets, $25 \mathrm{mg}$ supplied by Squip Co.

\section{Animals used:}

108 male albino rats were used throughout this study. At the begining of the experiment, the rats were aged 2 weeks. Food intake was recorded daily \& their weight was monitored weekly, they were put under similar 
housing condition. They were divided into 6 experimental groups $(n=18$ per group)..

Group (1) : Control group, these animals received standard diet.

Group (2) : High fructose-fed rats. Rats received a diet in which fructose composed $33.64 \%$ of total carbohydrates (20).

Group (3) : Received standard diet \& metformin in a dose of $200 \mathrm{mg} /$ $\mathrm{kg} /$ day intragastric in water in last 3 weeks of the study (20).

Group (4) : Received highfructose diet for 9 weeks and metformin treatment with the previous dose in the last 3 weeks.

Group (5) : Received standard diet for 9 weeks and captopril treatment in a dose of $2 \mathrm{mg} / \mathrm{kg} /$ day intragastric in the last 3 weeks (21).

Group (6) : Received highfructose diet for 9 weeks and captopril in the previous dose in the last 3 weeks. The diets composition are described in (Tab.1)

Data are given in grams per $100 \mathrm{~g}$ of dry weight. The salt mixture is expressed in grams per kilogram: $\mathrm{CaH}$ PO4, 30g; KCL, $100 \mathrm{~g} ; \mathrm{NaCL}, 100 \mathrm{~g}$; $\mathrm{MgO}, 10.5 \mathrm{~g} ; \mathrm{MgSO} 4,50 \mathrm{~g} ; \mathrm{Fe} 2 \mathrm{O} 3$, $3 \mathrm{~g}$; and $\mathrm{FeSO} 4 \mathrm{H} 2 \mathrm{O}, 5 \mathrm{~g}$. Vitamins Vol. 32, No. 1 \& 2 Jan. \& April, 2001 are expressed per kilogram of the vitamin mixture: retinol, $539 \mathrm{mg}$; cholecalciferol, $6.250 \mathrm{mg}$; thiamine, 2,000mg; riboflavin, 1,500 mg; niacin, $7,000 \mathrm{mg}$; pyridoxine, $1,000 \mathrm{mg}$; cyanocobalamin, $5 \mathrm{mg}$; menadione, $1,000 \mathrm{mg} / \mathrm{kg}$; nicotinic acid, $10,000 \mathrm{mg}$; o-choline, 136,000 mg; folic acid, $500 \mathrm{mg} ; \mathrm{p}$-aminobenzoic acid, $5,000 \mathrm{mg}$; and biotin, $30 \mathrm{mg} / \mathrm{kg}$.

\section{Insulin sensitivity assay:}

In 6 animals of each group, insulin sensitivity was performed according to Surwit et al. (22). Rats fed either the standard diet or the high fructose diet fasted for 4 hours \& injected intraperitoneally with regular insulin at $1 \mathrm{U} /$ $\mathrm{kg}$ body wt. Insulin was diluted in sterile saline for a final injected volume of $100 \mu \mathrm{L}$. Plasma was collected for glucose quantification before injection \& at $15,30,90$ minutes after insulin injection.

\section{Intravenous glucose toler-} ance test (IVGTT):

In 6 animals of each group IVGTT was done according to Rizk et al. (23). Rats were fed standard diet or high-fructose diet, fasted over night (18hs) and injected IV glucose in a dose of $1 \mathrm{gm} / \mathrm{kg}$ body wt. Plasma was collected for glucose quantification 
before injection \& at $0,15,30,60 \mathrm{mi}$ nuts after glucose injection.

At the end of the experiment the remaining 6 rats of each group were decapitated after 14 hours of starvation and blood collected. Blood samples were allowed to clot \& were centrifuged. Serum was separated \& frozen at $-70^{\circ} \mathrm{C}$ until time of the assay of the following parameters:

Serum glucose: according to the enzymatic glucose oxidase method of Trinder (24).

Fasting serum insulin: according to Morgan \& Lazarow (25) by radioimmunoassay using iodinated kit, manufactured by diagnostic production corporation.

Total serum cholesterol: using kits of biomerieux Co. according to Richmond (26), HDL \& LDL according to Burstein (27) using kits of Biomerieux Co. and $T G$ according to Fassati \& Prencipe (28) using TG kits of Biomerieux.

Serum tumour necrosis factor alpha (TNF- $\alpha$ ): according to Carti et al. (29) using a kit from immunotech (A Cloulter Co.) by enzyme linked immunosorbent

assay method.

\section{Statistics:}

Statistical analysis of the result were carried :ccording to Pipkin (30) using students " $t$ " test. $P$ is significant at $<0.05$.

\section{RESULTS}

Food consumption and weight of the rats: Throughout the experiment, all groups had similar food intake. After 6 weeks, the body weight of the rats was similar in all groups.

Insulin sensitivity (Tab. 2): Rats received high fructose diet developed a significant insulin resistance as evidenced by impaired response to IP. insulin dose of $1 \mathrm{u} / \mathrm{kg} \mathrm{BW}$. On the other hand rats fed standard diet showed a significant reduction in plasma glucose in response to IP. injection of insulin in a dose of $1 \mathrm{u} / \mathrm{kg} \mathrm{BW}$.

IVGTT (Tab. 3): Rats fed high fructose diet showed a significant impairment in response to IV glucose administration compared to rats fed standard diet. Administration of either metformin or captopril for 3 weeks to rats fed high fructose diet significantly improved the IVGTT. 
Effect of either metformin or captopril on fasting serum glucose, insulin, cholesterol, HDL, LDL, \& TG in rats fed either standard diet or high fructose diet (Tab. 4): Rats fed high fructose diet for 9 weeks showed a significant increase in fasting serum TG, LDL \& fasting serum insulin. On the other hand there was a significant decrease in HDL and no change in fasting serum glucose and cholesterol level.

Administration of metformin to rats fed high fructose diet in a daily dose of $200 \mathrm{mg} / \mathrm{kg} \mathrm{BW}$ intragastric in the last 3 weeks produced a significant decrease in serum fasting TG, LDL \& insulin \& TNF-( but it produced a significant increase in HDL \& no change in fasting serum glucose and cholesterol level (Tab.4).

Administration of captopril In daily dose of $2 \mathrm{mg} / \mathrm{kg}$ body wt. intragastric in the last 3 weeks to rats fed high fructose diet induced a significant decrease in fasting, LDL, TG insulin \& TNF- $\alpha$ but it induced no change in serum cholesterol and glucose levels. On the other hand captopril in the previous dose \& duration induced a significant increase in serum HDL (Tab.4).

Table (1): Diet composition of standard and high fructose diet (20).
\begin{tabular}{|l|c|c|}
\hline & Standard diet & High fructose diet \\
\hline \hline Glucose & 38 & 15.96 \\
\hline Fructose & - & 33.64 \\
\hline Wheat starch & 20 & 8.40 \\
\hline Casein & 23 & 23 \\
\hline Cellulose & 6 & 6 \\
\hline Corn oil & 5 & 5 \\
\hline Salt mixture & 7 & 7 \\
\hline Vitamins & 1 & 1 \\
\hline
\end{tabular}




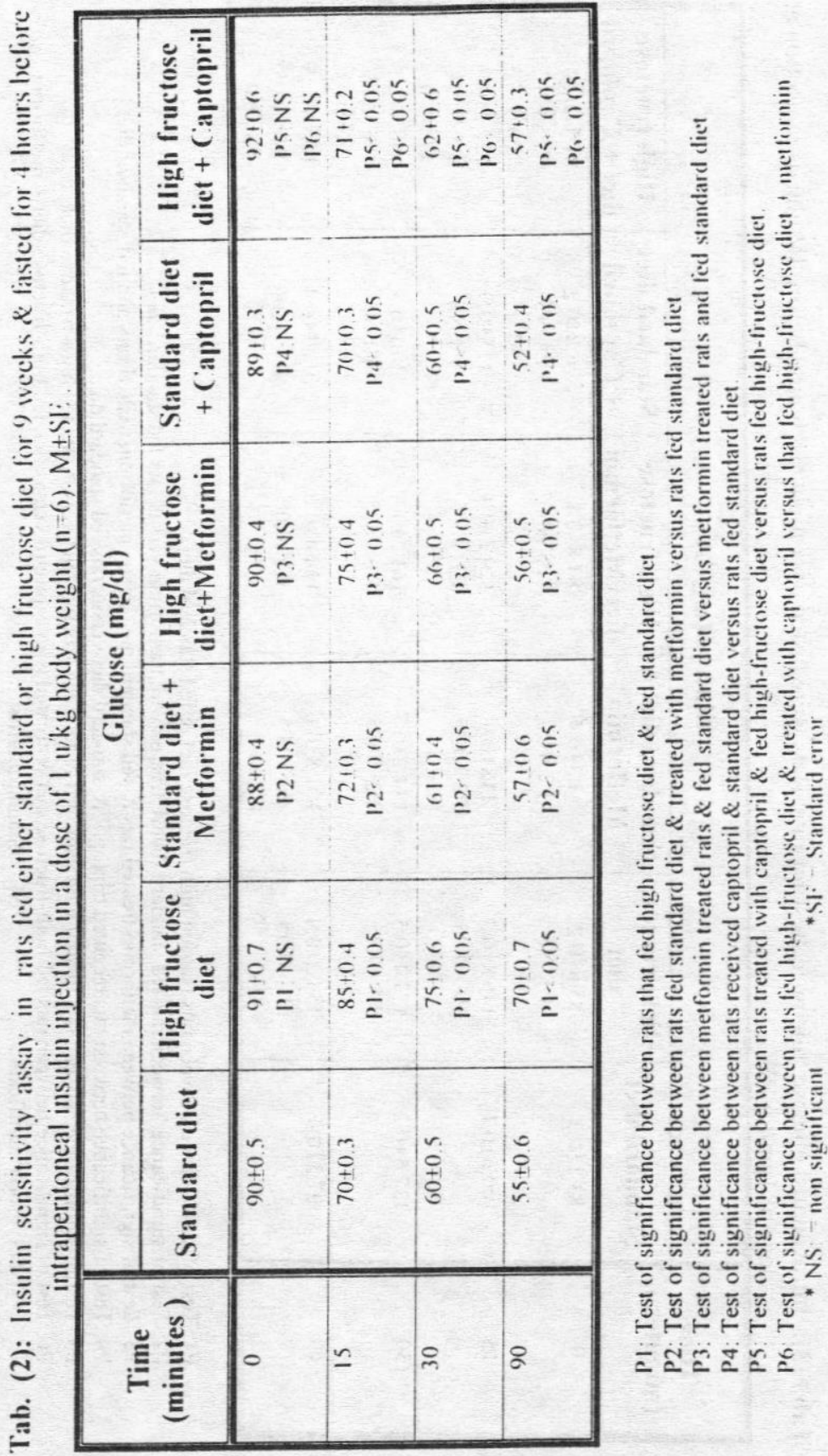




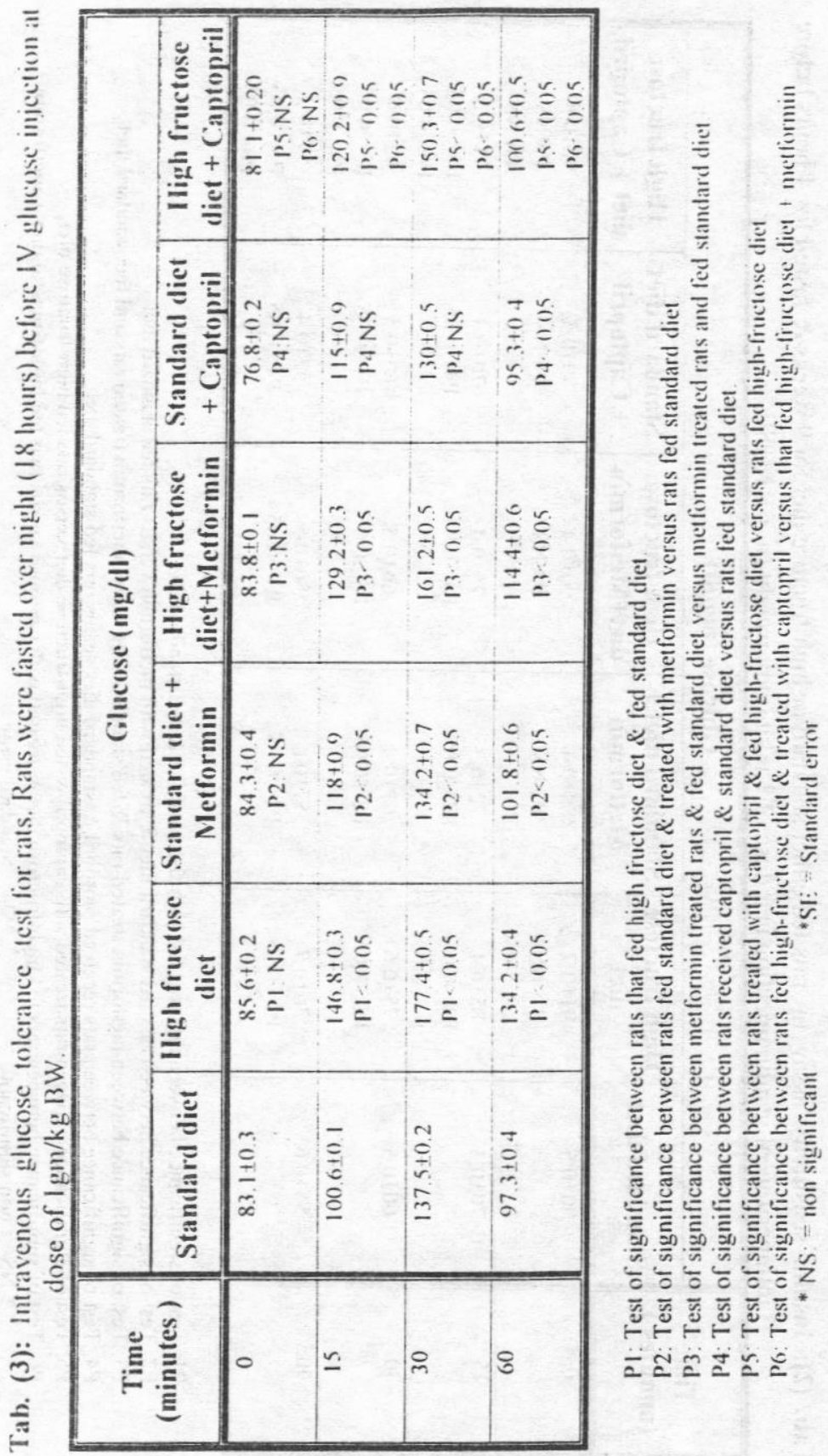

Vol. 32, No. 1 \& 2 Jan. \& April, 2001 


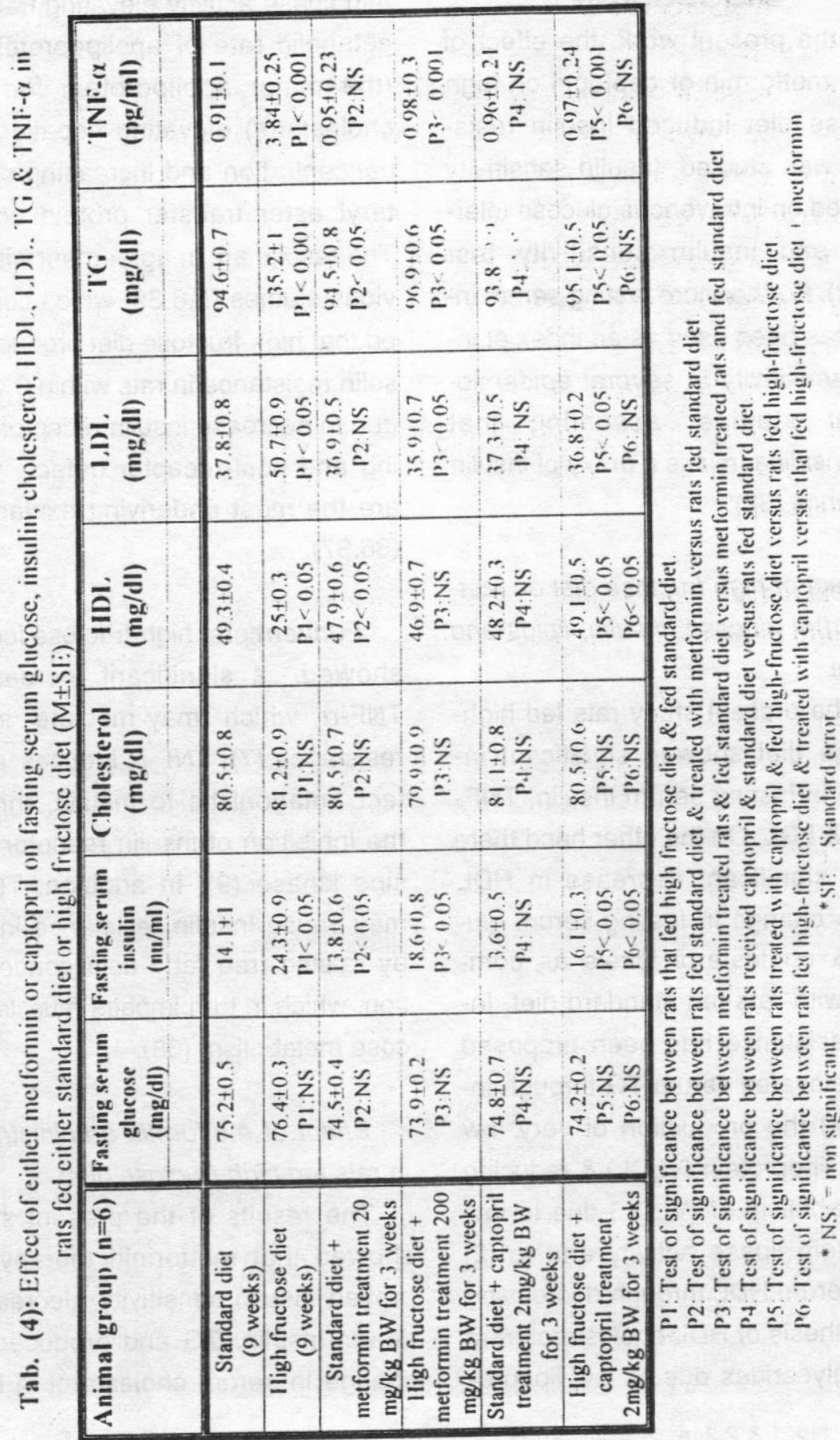




\section{DISCUSSION}

In the present work, the effect of either metformin or captopril on high fructose diet induced insulin resistance was studied. Insulin sensitivity is based on intravenous glucose tolerance and insulin sensitivity test $(31,22)$. Furthermore fasting serum insulin has been used as an index of insulin sensitivity in several epidemiological studies, assuming that hyperinsulinaemia is a proxy of insulin resistance (32).

Effect of high fructose diet on fasting serum glucose, insulin, lipids and $T N F-\alpha$ :

In the present study rats fed highfructose diet showed significant increase in fasting serum insulin, TNF. $\alpha, T G \&$ LDL. On the other har,d there was a significant decrease in HDL and no change in fasting serum glucose \& cholesterol levels as compared with rats fed standard diet. Insulin resistance has been proposed to: [1] elevated serum TG through increasing the production of very low density lipoprotein (VLDL) \& reducing the catabolism of (VLDL) due to low lipoprotein lipase activity and to [2] lower serum HDL through decreasing the synthesis of HDL-cholesterol from LDL-triglycerides due to low lipopro- tein lipase activity elevating fractional cataholic rate of apolipoprotein A-1 (the major apoliporotein for HDLcholesterol) elevating hepatic lipase concentration and increasing cholesteryl ester transfer protein activity. ine results are in agreement with previous studies $(5,6,35)$ which concluded that high-fructose diet produced insulin resistance in rats within 6 weeks due to decrease insulin receptor binding and post-receptor defects which are the most underlying explanation $(36,37)$.

Furthermore, high-fructose fed rats showed a significant increase in TNF- $\alpha$ which may mediate insulin resistance (7). TNF- $\alpha$ induces an effect antagonistic to insulin, through the inhibition of insulin receptor tyrosine kinase (9). In addition, TNF- $\alpha$ may cause insulin resistance in vivo by raising free fatty acid concentration, which in turn impairs muscle glucose metabolism (38).

Effect of metformin administration in rats fed high-fructose diet:

The results of the present study showed that metformin therapy improved insulin sensitivity, decreased serum insulin, TG and produced no change in serum cholesterol in high Vol. 32, No. 1 \& 2 Jan. \& April, 2001 
fructose fed rats. These findings were in accord with Tobey et al. (39) and Faure et al. (20) who reported that the improvement of insulin sensitivity produced by metformin may be due $2:$ is potential antioxidant effect.

Furthermore metformin improved glucose uptake by the peripheral tissues which could result from increased insulin binding to its membrane receptors, from the activation of post-receptor metabolic pathways as well as from a beneficial effect on lipid metabolism $(40,41,42)$.

Metformin administration in rats fed high fructose diet induced a significant increase in HDL and a significant decrease in LDL. These findings were in agreement with Perrillo et al. (43). This could be explained on the basis that metformin improved insulin resistance. In addition, metformin induced a significant decrease in TNF- $\alpha$ in high fructose-fed rats which may explain the improving of insulin sensitivty. The finding of Dan Don et al. (7) supports this result as they reported that a fall in TNF- $\alpha$ concentration contributes to the restoration of insulin sensitivity.

Effect of captopril administration in rats fed high-fructose diet:

Administration of captopril to high fructose fed-rats induced improvement in insulin sensitivity associated with a significant decrease in serum TG, insulin and produced no change in serum cholesterol levels. These findings are in accordance with previous studies $(14,15,16)$. They reported that in human \& animal models of insulin resistance, ACE inhibitors increase sensitivity to insulin. Most previous investigations have attributed the influence of ACE inhibitors on glucose disposal to improved capillary blood flow \& an accompanying increased delivery of insulin \& glucose to muscle $(44,45)$. Other investigators indicated that the improvement of insulin sensitivity following treatment with ACE inhibitors was due to increase in insulin-induced insulin receptors and insulin receptor substrate-1 phosphorylation (IRS-1) as well as IRS-1 phosphatidylinositol (PI-3) kinase association. Furthermore in the liver and muscle (21) it has been suggested that captopril induced improvement of insulin sensitivity via endothelin-1 inhibition(19). Endothelin-1 has potent glucogenolytic effect on hepatocytes \& may cause insulin resistance in rat adipocyte.

MANSOURA MEDICAL JOURNAL 
Furthermae, captopril induced a significant decrease in TNF- $\alpha$ in high fructose fed rats as compared to rats fed standard diet treated with captopril. As TNF- $\alpha$ induced an effect antagonistic to insulin through the inhibition of insulin receptor tyrosine kinase

(9), so the normalization of TNF- $\alpha$ levels can explain the improvement of insulin sensitivity with capto pril treatment.

\section{Conclusions:}

The present results provided additional evidence that feeding rats with high dosage of fructose leads to insulin resistance. On the light of this study, it could be concluded that captopril and metformin treatment has a comparable beneficial effect in the reversal of insulin resistance and its accompanying metabolic changes. TNF- $\alpha$ may be an important circulating cytokine which may provide a potentially reversible mechanism for mediating insulin resistance. Furthermore both captopril and metformin might prove useful in the treatment and/or preventing nonhyperglycaemic insulin resistance states such as obesity and impaired glucose tolerance as well as in the treatment of established NIDDM.

\section{REFERENCES}

1- Grunfeld, C and Feingold H.R. (1992) : Metabolic disturbances and wasting in the acquired immunodeficiency syndrome. N. Eng. J. Med. 327:329-337.

2- Copeland, G.P., Leinster, S.P., S. J. Davis, J.C. and Hipkin L.J. (1987) : Insulin resistance in patients with colorectal cancer. Br. J. Surg. 74:1031-1035.

3- Moller, D.E., and Flier J.S. (1992) : Insulin resistance: mechanisms, syndromes, and implications N.Engl. J. Med. 325-9.

4- Reaven G.M. (1993) : A syndrome of resistance to insulin stimulated uptake (syndrome-X). Definitions and implication. Cardiovasc. Risk factors 3:2-11, 1993.

5- Laakso M. (1993): The possible pathophysiology of insulin resistance syndrome. Cardiovasc. Risk factors 3:55-66.

6- Faure P., Rossini E., Lafond JL, 
Richard M.J., Favier A \& Halimi S. (1997) : Vitamin E improve the free radical defense system potential and insulin - sensitivity of rats fed - high - fructose diets. J. Nutr. 123:103-107.

7- DanDona P., Weinstock R., ThLsu \& Abdel-Rahman E (1998) : Tumour necrosis factor (in sera of obese patients: fall with weight loss. J. Clin. Endocrinol Metab. 583 (6): 2907-2910.

8- Hotamisligil G.S., Shargill N.S., \& Spiegelman B.M. (1993) : Adipose expression of tumour necrosis factor- $\alpha$ direct role in obesity-linked insulin resistance. Science; 259:87-91.

9- Hotamisligil GS, Budavari A, Murray $D$ \& Spiegelman BM (1994) : Reduced tyrosine kinase activity of the insulin receptor in obesity \& diabetes, central role of tumour necrosis factor- $\alpha$. J. Clin. Invest.; 94:1543-1549.

10- Kern PA, Saghizadeh M, Ong
JM, Bosch RJ, Deem R \& Simsolo RB (1995) : The expression of tumour necrosis factor in human adipose tissue. Regulation by obesity, weight loss and $r e$ lationship to lipoprotein lipase J. Clin. Invest. 95:2111-2119.

11- Stumvoll M, Murjhan, N, PerrielIo G, Dailey G \& Gerich JE (1995) : Metabolic effects of metformin in non-insulin dependent diabetes mellitus. N. Engl. J. Med. J. 333:550-4.

12- Inzucchi SE, Maggs DG, Spollett GR, Page SL \& Rife FS (1998) : Efficacy \& metabolic effects of metformin \& troglitazone in type II diabetes mellitus. N. Engl. J. Med.; 338:867-72.

13- Kolodjiejczyk B, Duleba J, Spaczynski Z \& Pawelczyk L (2000): Metformin therapy decreases hyperandrogenism and hyperinsulinemia in women with polycystic ovary syndrome. Fertil \& Steril 573 (6): 1149-1154.

MANSOURA MEDICAL JOURNAL 
14- Henriksen EJ \& Jacob S (1995)

: Effects of captopril transport activity in skeletal muscle of obese zucker rats. Metabolism; 44: 267-272.

15- Donnelly R (1992) : Angiotensin converting enzyme inhibitors and insulin sensitivity, metabolic effects in hypertension, diabetes, and heart failure. J. Cardiovasc. Pharmacol 20 (suppl.11): 538-544.

16- Henriksen EJ, Jacob S, Augustin IJ \& Dietze GJ (1996) : Glucose transport activity in insulin resistant rat muscle effect of angiotensin converting enzyme inhibitors and bradykinin antagonism. Diabetes 45 (suppl.1) 5125-5128.

17- Herings RMC, Boer A, Stricher B \& Leufkens HGM (1995) : Hypoglycaemia associated with use of inhibitors of angiotensin converting enzyme. Lancet; 345:11951198.

18- Carla RO, Carvalho AC, Jose AR \& Licio AV (1997) : Ef- fect of captopril, losartan and bradykinin on early steps of insulin action. Diabetes; 46:1950-1957.

19- Lam HC, Lee JK, Chiang HT, Chunang MJ \& Wang MC (1998) : Is captopril induced improvement of insulin sensitivity via endothelin ? J. cardiovascular pharmacol; 31 (suppl.1): S 496-500.

20- Faure P, Rossini E, Wiensperger N \& Favier A (1999): An insulin sensitizer improves the free radical defense system potential and insulin sensitivity in high fructose fed rats. Diabetes; 48: 353-357.

21- Carvalho CRO, Thirone ACP, Gontijo JAR, Velloso LA \& Saad MJA (1997) : Effect of captopril, losartan, and bradykinin on early steps of Insulin Action. Diabetes; 46:1950-1957.

22- Surwit RS, Seldin MF, Kuhn CM, Cochrane CC \& Feinglos MN (1988) : Diet induced type II diabetes in 
C57BI6J mice. Diabetes; 37:1163-1167.

23- Rizk NM, Meier DA, Krakower GR \& Kissebah AH (1998) : Mechanism of insulin resistant glucose utilization in rat skeletal muscle. Molecular Genetics and Metab.; 63:126-133.

24- Trinder P (1969) : Enzymatic determination of glucose. Ann. Clin. Biochem.; 6:24-29.

25- Morgan RC \& Lazarow A (1963) : Immunology of insulin level of normal subdiabetic \& diabetic rats Diabetes; 12:115-126.

26- Richmond W (1973) : Enzymatic determination of cholesterol. Clin. Chem.; 19:1350-1356.

27- Burstein M (1970) : Determination of high density lipoprotein cholesterol level. Lipid Res.; 11:583.

28- Fassati M \& Prencipe L (1982) : Enzymatic determination of triglycerides. Clin. Chem.; 28:2077.
29- Corti A, Fassina G, Marcucci F, Barbanti E \& Cassani G (1992): Oligomeric Tumour Necrosis Factor-( slowly converts into inactive forms of bioactive level. Biochem J; 284:905.

30- Pipkin FB (1984) : Statistical analysis of the obtained data by descriptive and comparative analysis in: "Medical statistic Made Ease" Churchill livingstone puplication. London, Melbourne, New York.

31- Saad MF, Anderson RL, Laws A \& Watanable RM (1994): A comparison between the minimal model \& the glucose clamp in the assessment of insulin sensitivity across the spectrum of glucose tolerance. Diabetes; 43:1114-1121.

32- Haffiner SM, Valdez RA, Hazuda $\mathrm{HH}$, Mitchell BD, Morales PA \& Strern. MB (1992) : Prospective analysis of the insulin resistance syndrome (syndrome-X). Diabetes; 41:715-722.

MANSOURA MEDICAL JOURNAL 
33- Storlien LH, Oakes ND, Pan DA, Kusunoki $M$ \& Jenkins $A B$ (1993) : Syndromes of insulin resistance in the rat: inducement by diet and amelioration with benfluorex. Diabetes; 42: 457-462.

34- Reaven GM (1991) : Insulin resistance, hyperinsulinaemia, hypertriglyceridemia, and hypertension parallels between human disease and Rodent models. Diabetes care 14:195-202.

35- Moon K, Philip DG, Mousak, Ke-Ming G, Moossa AR and Jerrold MO (1994) : Metabolic effects of troglitazone on fructose-induced insulin resistance in the rat. Diabetes; 43:14351439.

36- Beck-Nielsen $\mathrm{H}$, Pedersen $\mathrm{O}$ \& Sorensen NS (1975) : Effects of diet on the cellular insulin binding and the insulin sensitivity in young heaIthy subjects. Diabetologia; 15:289-296.

\section{7- Tuovinen CGR \& Bender AE}

(1975) : Some metabolic effects of prolonged feeding of starch, sucrose, fructose and carbohydrate free diet in the rat. Nutr Metab; 19:161-172.

38- Garg A (1996) : Insulin resistance in the pathogenesis of dyslipidema. Diabetes care; 19 : 387-389.

39- Tobey TA, Mondon CE, Zavaronei I \& Reaven GM (1982) : Mechanism of insulin resistance in fructose fed rats. Metabolism in 331: 608 612.

40- Prato SD, Enzi G \& Vigili S (1990): Insulin regulation of glucose and lipid metabolism in massive obesity. Diabetologia; 33: 228-236.

41- Klipa \& Leitrer LA (1990): Cellular mechanism of action of metformin. Diabetes care 513:696-704.

42- Benzil L, Trischuttav, Ciccarose A, Cechetti P, Brunetti A, Squatrito $S$ \& Marchetti $P$ 
Somaia A. Mokbel \& Karawan M. Abdel Rahman (1990) : Improvement with metformin in irisulin internalization and processing in monocytes from NIDDM patients. Diabetes; 39:844849.

43- Perriello G, Misero cardia P \& Volpi E (1994) : Acute antihyperglycemic mechanism of metformin in NIDDM: evidence for suppression of lipid oxidation \& hepatic glucose production. Diabetes; 43:920-928.

44- Miles PDG, Romeo OM, Higok,
Cohen A, Rafaat K \& Olefsky JM (1997): TNF- $\alpha$ induced insulin resistance in vivo \& its prevention by troglitazone. Diabetes; 46 : 1678-1683.
45- Uehara M, Kishikawa H, Sami S \& Kisanuki K (1994) : Effect on insulin sensitivity of angiotensin converting enzyme inhibitors with or without a sulphydryl group bradykinin may improve insulin resistance in dogs \& humans. Diabetologia; 37:300-307. 
دراسة مقارنة لكل من دوائى ألميتفورمين والكابتوبريل على حساسية الأنسولين فى الفئران البيضا ؛ مله التى تغذت على كمية كبيرة من سكر الفركتوز

$$
\begin{aligned}
& \text { د. سومية عبد اللطيف مقبل . ـ كروان محمد عبد الرحمن } \\
& \text { قسم الفارماكولوجى الإكلينيكى - طب المنصورة }
\end{aligned}
$$

أجرى هذا البحث لدراسة ومقارنة التأثير الإيجابى لكل من المبتنورمين أو الكابتوبريل على حساسية

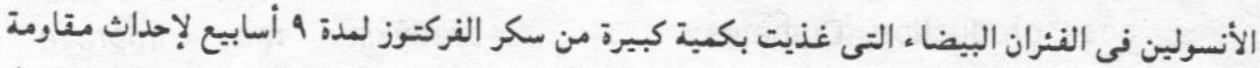

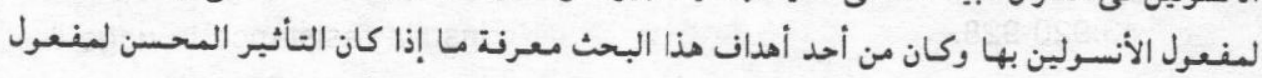

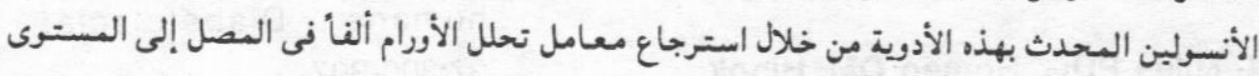

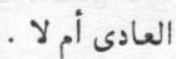

استخدم فى إجراء هذا البحث عدد 1 ـ ا أنار أبيض، وتسمت إلى ل مجموعات متسارية، كل منها يتكون من \ا نزر كالتالى :

المجسوعة الأولى ضابطة غذيت بطعام لايحتوى على نسبة عالية من سكر الفركتوز (غذاء

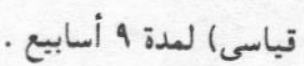

المجموعة الثانية : غذيت بطعام يحتوى على نسبة عالبة من سكر الفركتوز لنفس المدة السابقة.

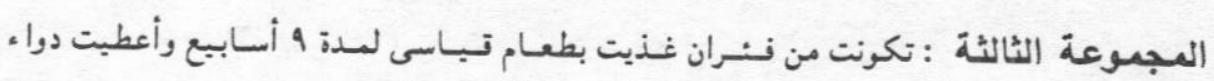
الميتفورمين بالفم بجرعة . . . مبم/كجم يوميا خلال الثلاثة أسابيع الأخيرة.

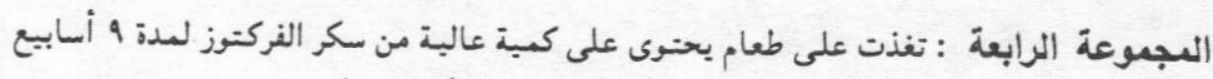

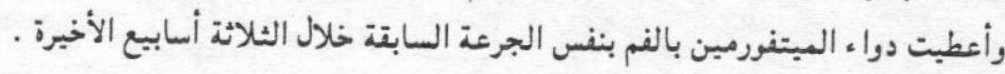
المجسوعة الذامسة : تغذت على الطعام القباسى لمدة ه أسابيع وأعطبت دواء الكابتوبريل بالفم

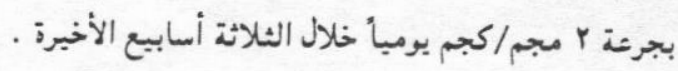


المجسوعة السادسة : تكونت من فنران غذيت بطعام يحتوى على نسبة عالية من سكر !لفركتوز لمدة ه أسابيع وأعطيت دواء الكابتوبريل بالفم بنفس الجرعة السابقة خلال الثلاثة أسابيع الأخيرة .

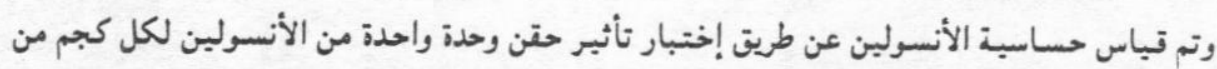

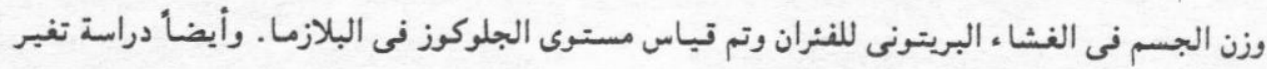

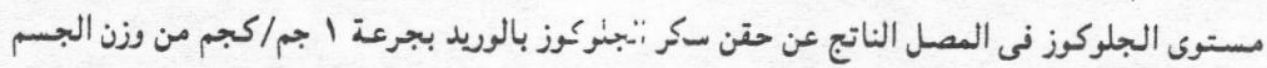

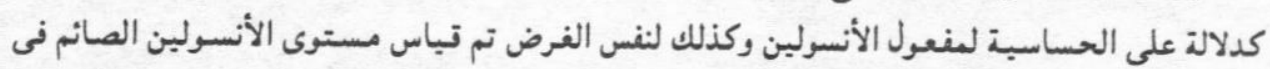

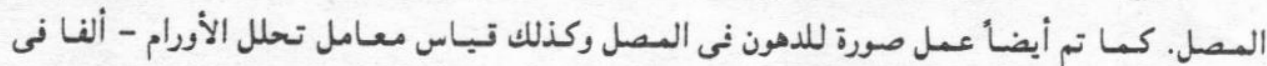

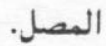

\section{ويعن تلخيص نتائج هذا البحث كما يلى :-}

تغذية الفثران بطعام يحتوى على نسبة عالية من سكر الفركتوز لددة 4 أسابيع أدى إلى إحداث مقاومة

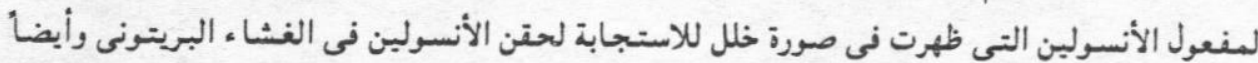

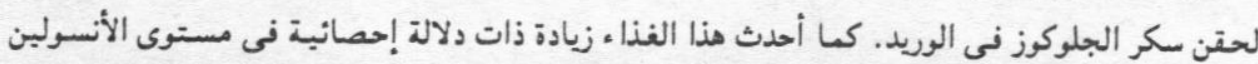

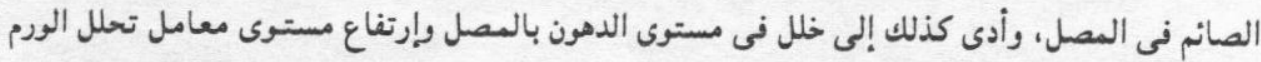

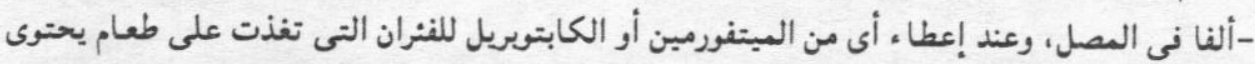

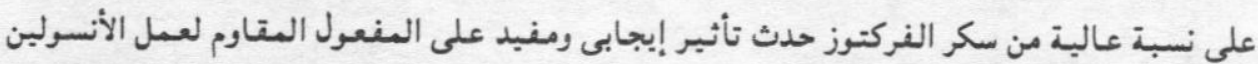
الصائم ومعامل تحلل الأورام - ألفا فى المصل أيضاً .

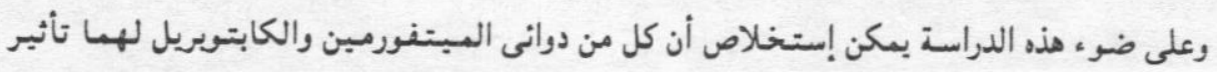

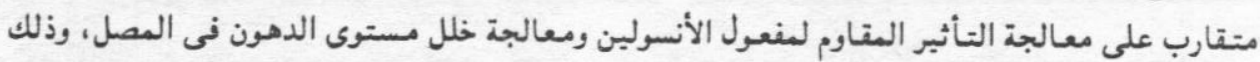

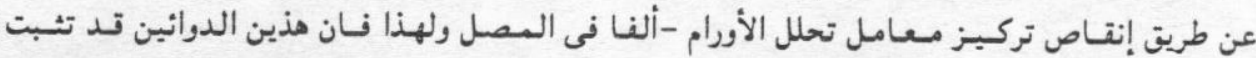
فائدتها فى الحالات التى تعانى من مقاومة مفعول الأنسولين . 
